\title{
Tolerance in Dealing with Different Mazhab (Schools of Islamic Thought) in Makassar City
}

\author{
Muammar Muhammad Bakry \\ Alauddin State Islamic University of Makassar \\ muammarbakry@yahoo.com
}

\begin{abstract}
This paper discusses the development of tolerant character in dealing with the differences of mazhab fiqh (school of thought within Islamic jurisprudence) through the development of four aspects, namely spiritual and emotional, intellectual, physical and kinesthetic, as well as affective and creativity. These four aspects become the standard of assessing religious tolerance in Makassar City. The more scholars have mujtahid (one who is empowered to interpret legal issues not explicitly address in the Qur'an) capacity, the more fertile and flourishing fiqh 'flowers' produce a fresh and natural scent will be. As a result, it will impact on the dynamics and variations of worship practices that can refresh the umat (Islam followers) in dynamic nuances. One of the indicators of a flourishing fiqh is seen from different opinions or ikhtilaf ulama (scholarly religious disagreement) that occur among the fuqaha (Islamic jurists). Hence, fiqh is one of the Islamic teachings that upholds and appreciates tolerance and moderation of opinions, as well as opens the opportunity for the widest possible divergence of views. The freedom to choose which mazhab or ulama (Islamic scholar) as a role model is individual rights in Islam. Nevertheless, a proper and profound attitude toward the essence of fiqh will avoid fanaticism, and increase one' $s$ tolerance instead. This is what we call educating umat to be tolerant in practicing Islam.
\end{abstract}

Keywords: tolerance, differences, mazhab

\section{INTRODUCTION}

Difference is inevibility. Humans are naturally born as a male or female. Humans come from different tribes, nations, languages, and cultures. These differences bring about varieties in character, science, and religious interpretation.

Forcing to unite and equate man in one thought is contrary to the human nature. In other words, this action can mean challenging God's omnipotence. Even if God could unite all human beings, but $\mathrm{He}$ create differences so humans can learn invaluable lessons from the differences.

Therefore, having an accepting attitude is a gift from God and shows that one is a broad-minded person. Being tolerant of differences is a good quality in someone that positively impact on the way one understands truth according to the most reliable dalil (reasoning or inference).

Differences of opinion is something natural. Although it often leads to a clash of opinions among the ulama and later creates mazhab fiqh, yet it is actually a grace and convenience for Muslims. Various ijtihad (independent reasoning) of ulama has become Islamic treasures and pride for their umat.

Differences in fuqaha only occur in secondary problems (furui'yyah), not the primary ones like aqidah (creed). The ultimate difference of ulama is in the level of human understanding in capturing messages and meaning, drawing legal conclusions, understanding the secrets of shari'a (Islamic law) and understanding 'illat (reason) of law. All of this does not contradict the shari'a, because all Islamic shari'a does not contradict one another. In other words, differences occur due to human limitations and weaknesses.

Religious practices and rituals of Islam have been believed to have originated from the Prophet Muhammad saw, which was interpreted and taught by the ulama from time to time. When the Prophet was still alive, their companions often expressed different views, let alone in the present time, thousands of years away from the Prophet era. Ulama practice the religion upon perusing hadits (narrations concerning the actions and orders of prohet Muhammad) that are considered sahih (authentic), which is further applied in their practice of worship and muamalah (worldly matters)

Muslims who are still novice in religious matters usually follow the teachings of certain teachers or ulama in practicing Islam. The atmosphere of internal tolerance among Muslims sometimes becomes the trigger of mazhab fanaticism. Among them, there were those who claimed Shafi'i followers but turned out to be "more Shafi'i" than Imam Shafi'i, or "more Hanbali" than Imam Hanbali. Even there are those claim that they do not conform to any mazhab, but apparently the way they practice Islam is often related to certain $m a z h a b$, or combine between one mazhab and another (talfiq).

Due to the social phenomena arises, khilafiyah (different opinions) likely to intensify, and even lead to internal debate among umat. The ceremonies (tahniah and $\left.t a^{\prime} z i a h\right)$ with certain tradition and ritual, the series of prayers such as reading basmalah, qunut, reciting 
$d u$ 'a together after sholat (prayer), clothing, growing the beard, are some sources of dispute that later divide Muslims into various groups. Even worse, the group often blames each other without trying to see such differences as a variety of Islamic treasures.

In addition to the cases discussed above, thare are many other cases that will present if we are not able to prioritize things that matter the most. A failure to understand the priority scale will even lead to negative things.

This gives a simple but substantive illustration of how difficult some people correctly put the values of life in the composition of maslahat-mafsadat (social utility-disutility), large-small, high-low, primarysecondary, universal-particular, and how the imbalanced composition can result in mental oppression and variety of Islamic religious practices.

This paper hghlights the religious practices and rituals of Islam, especially in Makassar (the capital city of South Sulawesi). Some of the reasons for choosing Makassar is because the population consists of diverse ethnic backgrounds (Bugis, Makassar, Mandar, Toraja, Jawa, etc.), religion, ideology (sunni, syiah, etc.) and other pluralities.

This paper attempts to answer the following questions:

1. How do Muslims respond to different perceptions of ulama?

2. How is the practice of following certain mazhab among ulama and common people in Makassar?

3. How do people respond to different religious practices among Muslims in Makassar?

\section{RESEARCH METHOD}

The method used in this research is ushuliyah tasyri'iyyah and ijtima'iyah. The former is used to explain different views of ulama in terms of legal arguments, which are further compared (muqaran) to objectively assess the differences, while the latter is used to explain the social phenomena related to various religious practices and rituals of Islam.

To understand the social phenomena in Makassar, the author conducted interviews with several administrators and jamaah masjid (a group of people praying in mosques) in South and North Makassar. The southern region was dominated by Muhammadiyah and Wahdah Islamiyah followers, while the northern region by Nahdhatul Ulama followers.

\section{DISCUSSION}

Differences can be seen in appearance, attitude or opinion. Differences are more common than feuds. It is because people who are in conflict must have differences, but not everyone with differences are necessarily in conflict.

For the increasing number of differences, there are some Arabic vocabularies often used to describe 'differences', such as aljadal (arguing) and syiqaq (quarreling).

When two parties are argueing to defend their respective views, each side argues for strengthening their views and weakening the views of others. This activity is called al-jadal. But if the angers or tensions peak between two parties, which is usually accompanied by the subjectivity and inability to think clearly, then this situation is called syiqaq [1].

In the history of tabi'tabi'in, the unity of Muslims (tawhīd shufüf al-muslimīn) was a priority. It was believed that fraternity in Islam that make each other's closer was more important than others. Therefore, persons who conform to this belief are often holding back their opinions in congregation religious practice, even though he believes his opinion is the right one. There is a principle underlying congregation religious service, namely "fi'lul mafdhūl wa tark al-fādhil", which means that one is willing to practice a certain way based on opinion that he does not consider as having a strong foundation, and choosing to leave his opinion that he thought having a stronger basis [2]

This attitude will create an atmosphere of tolerance and mutual respect in religious practices and rituals of Islam. Some examples of this situation include an imam (religious leader) who thinks that reciting qur'an out loud during congregation prayer is better but chooses not to do it because it follows the majority of the followers who prefer to do otherwise; or an imam who argues that qunut is not recommended in the morning prayer, but decides to still recite it for the majority of the followers consider it advisable. The classical ulama usually do this, with the hope that the furu'iyyah problem will not lead to the internal divisions of the umat, but rather make it more united.

According to Abu al-Ashim [3], the imam of mazhab like Imam Ahmad and others believed that "... an imam should leave even the recommended things in order to unite the hearts of the umat. In the case of witir prayer, the imam should follow the condition of the followers who do not perform witir prayer, except by way of fashl or leaves one raka'at at the end of prayer.

\section{Religious practice and rituals of Islam in Makassar}

In Indonesia, the majority of Muslims follow mazhab Syafi'iyah in practicing Islam, especially in performing sholat. Even mazhab Shafi'iyah is immersed in the local culture and followed heartily. This is different from other Southeast Asian countries including Malaysia and Brunei Darussalam, who make the Shafi'iyah a well-structured part of the national constitution, which is exercised in the community's daily lives.

There are many factors that made mazhab Syafi'i become the mazhab with the most followers. One of which is Islam was brought to the country and disseminated by some ulama better known as wali songo ( 9 saints) in the past. The way they spread Islam throughout the country made it a well-accepted 
religion, and this early Islamic teaching followed mazhab Syafi'iyah.

Another factor that influenced the popularity of mazhab Syafi'iyah is the incorpartion of this mazhab into pesantren (Islamic boarding school) curriculum in Indonesia, which was later brought by the Islamic priests to the community in various places in the country including Makassar. The teaching of this mazhab was disseminated through lectures, sermons, or religious gatherings.

Lately, the religious practices and rituals of Islam in Indonesia, especially Makassar has had more and more varieties. The philosophy that began to grow massively in the form of caderization is often imposed by small groups that later become a mass organization. The groups include Shias, Salafiyah, Wahdah Islamiyah, LDII, Hizbu Tahrir Indonesia, and two popular mass organizations in Makassar, namely NU and Muhamadiyah.

In Indonesia, Shia has not become a mass organization, nor has it been legal, but as a religious ideology, it is difficult to stop it from spreading around the country. Moreover, Shia have been present at many campuses in Makassar as an alternative religious ideology. The followers have not been out publicly when practicing the rituals for it is feared that it causes conflicts that harm this minority group. Also, Shia teaches the concept of taqiyah as a way to blend in the middle of society who do not accept it. Nevertheless, in certain events such as Ashura, they started to 'show off' their tradition massively in a certain place in Makassar.

In fact, the practice of Shia has not been easily accepted by Sunni group. For example, Shia and Sunni differ in their call to prayer, which says "asyhadu anna aliyah waliyyallah" and "hayya 'ala khairil amal" respectively. Besides, the prayers Shia followers perform in jama' (combining two prayers in one time) without acceptable excuses is unusual for Sunni.

Thus, this study actually discusses the religious practice and rituals of Islam by Sunni in addition to Shia.

In addition to the Shia groups that began to spread in Makassar, there is a very massive group called Wahdah Islamiyah. This group's ideology represents Wahabiyah's teachings that follows mazhab Hanabilah.

In some religious matters, Wahdah Islamiyah is similar to Muhammadiyah, both of which practice Islam by way of religious purification. That is, both strongly oppose the practice of cultural tradition and consider it bid'ah (heretical). The tradition of reading Barazanji in some events in the northern part of Makassar is something that contradicts the authenticity of Islamic teachings, not to mention commemorations of Maulid, Isra Mi'raj. In this case, Al-jidal (debate) atmosphere adds to the dynamics of religious life in Makassar.

Wahdah Islamiyah was born as a group who holds the ideology of religious purification, which turns out to be more strict than its predecessor, Muhammadiyah. Even now, there seems to be no difference between
Muhammadiyah and NU in some cultural traditions including wedding party, commemoration of maulid, isra' mi'raj and many more.

The existence of Wahdah Islamiyah gives a sense of religious wahabization for some people in Makassar so the influence in the religious practice is not only present in the form of ikhtilaf (differences) but also in the form of jidal (debate). It can bee seen from the increasing number of Wahdah Islamiyah missionaries who blame and deny the religious culture practiced by most people in Makassar. Most people feel uneasy about this situation, but only a few people are affected by this systematic movement.

There are two largest mosques in Makassar, AlMarkaz al-Islami and Masjid Raya, which are both located in North Makassar. Both of these mosques are led by a priest who follows Ahl Sunnah wal jamaah (NU). Inspite of this, both the followers and the administrators of the mosques never argue or debate over it. Instead, they follow it wholeheartedly. Similarly, the same thing applies to some mosques in the southern part of Makassar, where the majority of Muslims neither recite basmalah loudly, read qunut at subuh prayer, perform sunnah (additional or recommended) prayer before maghrib prayer, nor perform wirid (prayers recited silently) in congregation after compulsory prayer.T he Muslims who traditionally perform prayers as practiced by $\mathrm{NU}$ followers do not mind following an imam who practice the teaching of different mazhab.

\section{CONCLUSION}

Difference is inevibility. Different views from different ulama create variations as an alternative choice for Muslims in practicing worship and muamalah according to individual or social conditions. These differences show that Islamic law is a very dynamic law, shalih li kulli zaman wa makan (providing guidance for all time and in all places).

The requirements of becoming a mujtahid ulama are getting more strict, while the problems faced by our society are becoming more and more complex. Hence, common people had better ask the competent ones to avoid making unnecessary mistakes or misunderstanding in practicing Islam. Indeed, it is better safe than sorry.

Different religious practices and rituals of Islam resulting from different mazhab seems normal in Makassar and categorized as ikhtilaf (varied). However, in some situations where Wahdah Islamiyah group is present, there is continuos debate over religious practice and rituals of Islam. Even so, it is still acceptable and does not lead to destructive activities like quarelling or fighting (syiqaq).

The situations discussed above can be maintained if the society respond to differences wisely so it helps to raise awareness of being a tolerant Muslim in furu'iyah (ancillary branches of religion)- an important character every Muslim should have. Therefore, Islamic scholars 
and leaders need to work together to educate the community to have tolerant character in their religious practices and rituals of Islam.

\section{REFERENCES}

[1] Thaha Jabir Ulwani, Adab al-Ikhtlaf fi al-Islam (USA: al-Ma'had al-Alami li al-Fikr al-Islami, 1981), p. 21.
[2] Muammar Bakry, Fiqh Priority Construction Methodology of Islamic Law (Jakarta: Pustaka Mapan, 2009), p. 7.

[3] Abu 'Ashim, al-Adillah' Ala I'tibar al-Mashalih wa al-Mafasid (al-Qahirah: t.p., 1991), p. 26. 